\title{
Environment rather than provenance explains levels of foliar phenolics in European beech (Fagus sylvatica L.) seedlings
}

\author{
Johanna S. Steen ${ }^{1} \cdot$ Johan Asplund ${ }^{1}$ (D) $\cdot$ Marit H. Lie ${ }^{1,2} \cdot$ Line Nybakken $^{1}$ (D)
}

Received: 24 September 2020 / Accepted: 16 April 2021 / Published online: 3 May 2021

(c) The Author(s) 2021

\begin{abstract}
With progressive climate change, the chemical defense in European beech (Fagus sylvatica L.) is likely to change, which might impact its fitness and ability to establish beyond its current northern distribution limit. We studied the phenolic defense in six beech provenances grown in three common gardens in Norway the two first years after planting.

We analyzed low molecular weight phenolic compounds by HPLC and condensed tannins by the acid-butanol assay. Sampling year explained most of the variance in phenolic defense, followed by environment (growing location), while the genetic background (provenance) showed the least explanatory power. After the first year in the field, the northernmost growing location had about $70 \%$ higher concentration of low molecular weight phenolics than the southern growing locations. The concentrations of condensed tannins, however, were lowest in the north. The mean concentration of total low molecular weight phenolics was twice as high after the first year compared to the second year. After the second year, the differences between the growing locations in many cases disappeared. The differences between the growing locations are probably caused by differences in temperature and soil fertility, while we attribute the decrease in low molecular weight phenols from the first to the second year to decreased water and nutrient stress, as well as aging. Our results suggest that intraspecific variations in concentration and composition of phenolic compounds in beech are caused by differences in the environment to a greater extent than the genetic background, which may indicate fast changes in chemical defense with climate change.
\end{abstract}

Keywords Plant secondary metabolites $\cdot$ Common gardens $\cdot$ Provenance trial $\cdot$ Carbon-based secondary metabolites . Secondary compounds $\cdot$ Chemical defense

\section{Introduction}

Global warming will have a pronounced effect on European forest ecosystems and might cause a shift in the competitiveness and dominance of species (Alkemade et al. 2011; Kellomäki et al. 2001). The global mean temperature is predicted to increase by $0.3-4.0^{\circ} \mathrm{C}$ by the end of this century, and the temperature at the northernmost latitudes is expected to increase even more than the global average (IPCC 2014).

Communicated by Porth.

Line Nybakken

line.nybakken@nmbu.no

1 Faculty of Environmental Sciences and Natural Resource Management, Norwegian University of Life Sciences, P.O. Box 5003, NO-1432 Ås, Norway

2 NLA University College, $\mathrm{Pb} 7153$ St. Olavs plass, 0130 Oslo, Norway
The frequency and severity of summer droughts is increasing (IPCC 2014), as well as the risk and intensity of pathogen infections and insect attacks (La Porta et al. 2008). More biotic and abiotic stresses pose threats to European tree species, which makes plant resistance more important than ever. In sum, climate change will bring changes in drought frequency and extent, changed UV-radiation, elevated temperatures and $\mathrm{CO}_{2}$, which may all impact the chemical and physical defense of plants (Julkunen-Tiitto et al. 2015; Zvereva and Kozlov 2006).

As the mean temperature in the northern hemisphere increases, keystone species in European forest ecosystems, like beech and spruce, shift northwards (Kramer et al. 2010; Bradshaw et al. 2000; Saltre et al. 2015). European Beech (Fagus sylvatica L.), hereafter beech, reaches its northern distribution limit in Southern Norway (Bjune et al. 2013). Plantings and natural regeneration from plantings are widespread along the coastline from the border between Sweden and Norway. Due to less intensive forestry practices and a 
warmer climate, some models predict beech to expand its range in Scandinavia (Kramer et al. 2010) but see (Saltré et al. 2015), and it is rapidly establishing in spruce monocultures. However, the acclimation and adaptation potential of the northernmost beech provenances beyond their present niche are scarcely studied.

An important aspect of adaptation and long-term survival of trees is their chemical defense. The phenolics comprise a large and highly abundant group of compounds occurring across the plant kingdom. They include phenolic acids, stilbenes, flavonoids, and tannins and play a vital role in plant defense against e.g., fungal pathogens (Ganthaler et al. 2017), insect and mammalian herbivores (Barbehenn and Constabel 2011), other plants (e.g., González et al. 2015) and UV light (e.g., Contreras et al. 2019). Some phenolic groups also function as antioxidants (Agati et al. 2012; Barbehenn and Constabel 2011). At unfavorable site conditions, such as low soil $\mathrm{pH}$, fertility, and moisture, we often find high levels of phenolics (Bussotti et al. 1998; Northup et al. 1998). They also affect nutrient cycling by inhibiting the decomposer community and reducing rates of nitrogen mineralization (reviewed by Min et al. 2015).

The intraspecific variation in phenolic composition and concentration is considerable (Moreira et al. 2014; Sampedro et al. 2011). It is influenced by season and age (Bussotti et al. 1998; Wam et al. 2017) as well as plant compartment, and phenolic content even varies between leaves of the same individual (Petrakis et al. 2011). The phenolic composition and concentration of an individual are partly decided by its genetic background but are also highly affected by the actual growing environment. However, few studies have attempted to quantify which of these factors explains more of the variation in phenolic compounds in beech (but see Zimmer et al. 2015). Common garden experiments have frequently been used to untangle the effects of genetics and environment on plant phenotypes (de Villemereuil et al. 2016). Several common garden experiments exist for beech, studying important aspects of fitness and survival, like drought resistance, growth, and phenology. To our knowledge, foliar phenolics have been studied only in a few of these: Zimmer et al. (2015) included only continental European provenances and growing locations, which might not be representative for beeches growing at the edges of the distribution range of the species, where environmental constraints are more severe. Furthermore, they included only data from one growing season and measured only total phenolic content. Aranda et al. (2017) compared foliar phenolics in three provenances, but used only one growing location, which makes it difficult to draw conclusions on how environment influenced the phenolic concentrations. Bussotti et al. (1998) investigated foliar phenolics in natural beech populations along an environmental gradient, but the study design did not allow for separation of genetic and environmental effects on foliar phenols. Comparison of environmental and genetic factors on foliar phenolics has been done for some other tree species like birch e.g., (Deepak et al. 2018; Laitinen et al. 2005), and aspen (e.g., Osier and Lindroth 2006), but defensive strategies of such pioneer species might not be representative for a late-successional species like beech (e.g., Zhang et al. 2018).

We explored the composition of phenolic compounds in beech seedlings of six European provenances originating from a latitudinal gradient, planted in three common gardens in Norway. The main goal was to quantify if the environment (growing location) or the genetic background (provenance) affected the concentration and composition of phenolic compounds more. If the phenolic concentration is under strong genetic control, adjustment to new growing locations will be slower, and the changes in foliar phenols due to climate change might be smaller. We aimed at testing the following hypotheses:

(1) Concentrations of phenolic compounds differ between planting locations and between provenances in the same planting location

(2) Concentrations of phenolic compounds change between the first and the second growing season in the field, as a result of adaptation to the new environment and/or aging

(3) The composition of phenolic compounds differs between provenances, planting regions, and sampling years

By testing these hypotheses, we aimed at filling some of the gaps in the understanding of the factors influencing the concentration and composition of the phenolic defense in beech. This is a small, but important part of the knowledge base needed to predict how beech will respond to climate change and the predicted increase in insect attacks, fungal pathogens, and severe weather events. As beech is a widespread tree species, this topic is of considerable importance to European ecosystems and forestry.

\section{Materials and methods}

\section{Study area and study species}

The study areas were located in Ås, Viken county in SE Norway, Re, Vestfold and Telemark county in SE Norway and Munkrøstad, Trøndelag county in central Norway (Fig. 1, Table 1). Munkrøstad has a lower mean annual temperature than Ås and Re, whereas the annual precipitation is lower than in Re while higher than in Ås. The light conditions are similar, as all growing locations are open and west- or eastfacing. All three planting locations were located on former agricultural land, and the sites in Ås and Munkrøstad had 


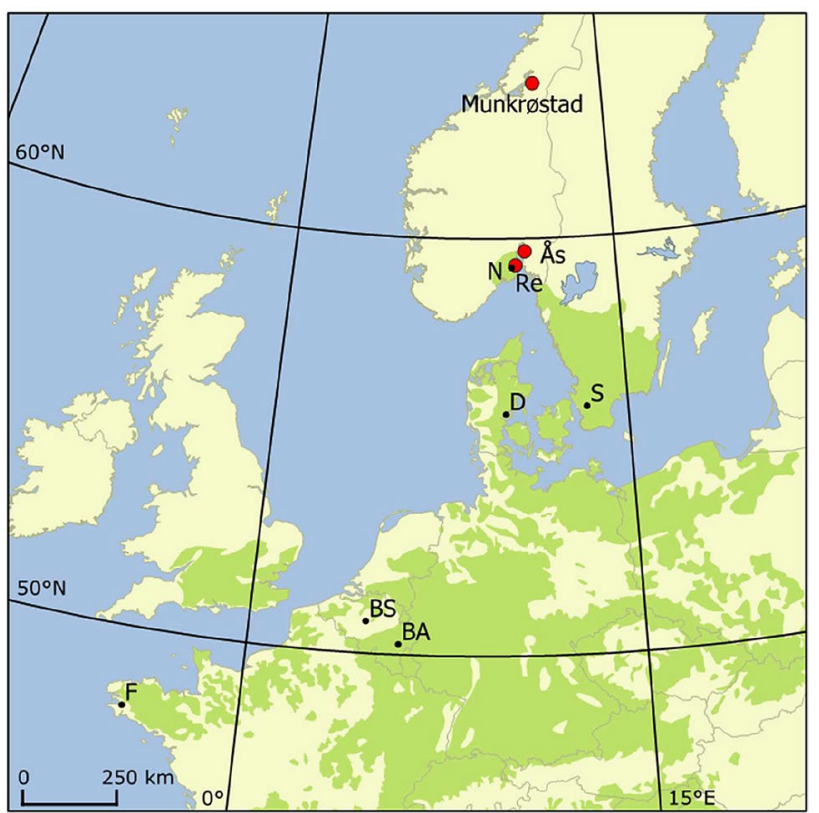

Fig. 1 Natural distribution of European beech (Fagus sylvatica; green areas) and the location of the three common gardens (red symbols) The black dots annotate the origins of beech seedlings used in the experiment: Norway (N), Sweden (S), Denmark (D), Belgium (de Soignes, BS), Belgium (Ardennes, BA) and France (F). See table 1 for more details on the provenance origins. The distribution map is adopted from the European Forest Genetics Programme http://eufor gen.org

Table 1 Coordinates, elevation, exposition, mean annual temperature (MAT), mean annual precipitation (MAP) and soil type (Geological Survey of Norway 2020) for the three common gardens in this experiment

\begin{tabular}{llll}
\hline & \multicolumn{2}{l}{ Location } & \\
\cline { 2 - 4 } & $\mathrm{Re}$ & As & Munkrøstad \\
\hline Latitude & $59^{\circ} 21^{\prime} 40.2^{\prime \prime} \mathrm{N}$ & $59^{\circ} 41^{\prime} 36.6^{\prime \prime} \mathrm{N}$ & $63^{\circ} 44^{\prime} 17.4^{\prime \prime} \mathrm{N}$ \\
Longitude & $10^{\circ} 18^{\prime} 50.7^{\prime \prime} \mathrm{E}$ & $10^{\circ} 45^{\prime} 06.9^{\prime \prime} \mathrm{E}$ & $11^{\circ} 24^{\prime} 01.3^{\prime \prime} \mathrm{E}$ \\
Elevation (m a.s.1.) & Appr. 80 & Appr. 90 & Appr. 100 \\
Soil type & Silty loam & Silty loam & Gravelly sand \\
Exposition & West/east & East/west & West/south \\
MAT $\left({ }^{\circ} \mathrm{C}\right)$ & 5.3 & 5.3 & 5.0 \\
GST 2016 $\left({ }^{\circ} \mathrm{C}\right)$ & 12.1 & 11.8 & 10.5 \\
GST 2017 $\left({ }^{\circ} \mathrm{C}\right)$ & 11.4 & 11.0 & 10.5 \\
DAM 2016 & 171 & 162 & 158 \\
DAM 2017 & 172 & 164 & 161 \\
MAP $(\mathrm{mm})$ & 1060 & 785 & 900 \\
GSP2016 $(\mathrm{mm})$ & 520.6 & 511.5 & 501.0 \\
GSP2017 $(\mathrm{mm})$ & 619.4 & 577.6 & 697.7 \\
\hline
\end{tabular}

Mean annual temperature and precipitation are calculated from the period 1961-1990. Growing season average temperature (Apr-Oct) (GST), Days above a minimum mean temperature according to Bolte et al. (2007) (DAM) and growing season average precipitation (GSP) for the years 2016 and 2017 were obtained from NIBIOs nearest climate station: Ramnes for Re, Ås for Ås and Kvithamar for Munkrøstad (NIBIO 2020) had one rotation of spruce before the experiment started. Silty loam, which is the soil type in Re and Ås, is generally more fertile than the gravelly sand in Munkrøstad and also more drought resistant (Ingels 2015).

The study species was European beech (Fagus sylvatica L.) of six European provenances: Vestfold (Norway), Stenderup (Denmark), Albjershus (Sweden), De Soignes (lowland, Belgium), Ardennes (Belgium) and Massif Armoricain (France) (Fig. 1, Table 2). The provenance origins form an approximate latitudinal gradient, with Massif Armoricain being the southernmost origin and Vestfold the northernmost origin. Bolte et al. (2007) defined climate restraints during the growing season for beech, and all three locations got much more precipitation than the minimum requirements for the growing season, whereas none of the locations meet Bolte et al.'s minimum requirement of 217 days per year with a mean temperature above $7^{\circ} \mathrm{C}$, neither in 2016 nor in 2017 (Table 1).

We received seeds from Sweden, Belgium, and France from commercial suppliers early autumn 2014 and put them on humid turf at $4{ }^{\circ} \mathrm{C}$ to break seed dormancy. When dormancy was broken, the seeds were stored at $-2{ }^{\circ} \mathrm{C}$ until planting in pots in a greenhouse in early Apr 2015. The seedlings from the Norwegian and the Danish provenances were purchased from a nursery (Reiersøl nursery, Grimstad, Norway), as seeds were not commercially available. The Norwegian provenance were received as 1-year old plug-plants, while the Danish provenance were 2-year-old bareroot plants. All seedlings were moved outdoors in pots in Ås in Aug 2015, where they stayed until mature winter buds were formed. The dormant seedlings were planted in Re and Ås in late Sep and Oct 2015. The plants destined for Munkrøstad were moved to a cold plant storage room and planted in May 2016, before bud break. The planting scheme was equal in all three locations: a $25 \times 12$ matrix with provenances in random order. The plantings were fenced, and ground vegetation was kept down to decrease browsing pressure and competition from other vegetation. Between sampling in 2016 and 2017, many plants were killed, likely by European water vole (Arvicola terrestris), and these plants were excluded from the analysis.

\section{Harvest}

Foliage sampling took place during the first week of Sep in both 2016 and 2017. Two fully developed leaves without visible signs of senescence about $5 \mathrm{~cm}$ below the top shoot were sampled from each beech sapling. The leaves were put into paper bags with silica, transported to the lab on the same day and dried for two days at $30{ }^{\circ} \mathrm{C}$ in an oven. The dried leaves were ground to a fine powder using a Retsch MM400 ball mill (Retsch, Haag, Germany), transferred to plastic vials and stored in the freezer $\left(-20{ }^{\circ} \mathrm{C}\right)$ until extraction. 
Table 2 Coordinates and climate data for the beech provenance origins in the experiment. MAT stands for mean annual temperature and MAP for mean annual precipitation

\begin{tabular}{llllcl}
\hline Country & Provenance & Latitude & Longitude & MAT $\left({ }^{\circ} \mathrm{C}\right)$ & MAP $(\mathrm{mm})$ \\
\hline Norway & Vestfold & $59^{\circ} 18^{\prime} \mathrm{N}$ & $10^{\circ} 08^{\prime} \mathrm{E}$ & 5.3 & 1060 \\
Sweden & Albjershus & $55^{\circ} 56^{\prime} \mathrm{N}$ & $13^{\circ} 15^{\prime} \mathrm{E}$ & 7.8 & 668 \\
Denmark & Stenderup & $55^{\circ} 47^{\prime} \mathrm{N}$ & $9^{\circ} 48^{\prime} \mathrm{E}$ & 7.7 & 725 \\
Belgium & De Soignes & $50^{\circ} 46^{\prime} \mathrm{N}$ & $4^{\circ} 24^{\prime} \mathrm{E}$ & 10.3 & 785 \\
Belgium & Ardennes & $50^{\circ} 15^{\prime} \mathrm{N}$ & $5^{\circ} 40^{\prime} \mathrm{E}$ & 7.5 & 1095 \\
France & Massif Armoricain & $48^{\circ} 06^{\prime} \mathrm{N}$ & $4^{\circ} 10^{\prime} \mathrm{W}$ & 10.4 & 1142 \\
\hline
\end{tabular}

\section{Phenolic extraction}

From each powdered sample, ca $10 \mathrm{mg}$ plant material was weighed on a microscale and transferred into a plastic vial together with 2-3 zirconium oxide balls. For the extraction, we added $400 \mu \mathrm{L}$ methanol $(\mathrm{MeOH})$ to the vial and homogenized the samples for $20 \mathrm{~s}$ at $5000 \mathrm{rpm}$, using a Precellys 24 homogenizer (Bertin Technologies, Montigny-le-Bretonneux, France).

The vial was put in an ice bath for $15 \mathrm{~min}$, and thereafter centrifuged for $3 \mathrm{~min}$ at 15,000 rpm, using an Eppendorf 5417C centrifuge (Eppendorf, Hamburg, Germany). The supernatant was transferred to plastic tubes using a Pasteur pipette. $400 \mu \mathrm{L} \mathrm{MeOH}$ was then added to the residue and the vial was homogenized for $20 \mathrm{~s}$ and then centrifuged for $3 \mathrm{~min}$. The supernatant was again transferred into the same plastic tube. We repeated the process four times so that $\mathrm{MeOH}$ was added 5 times to the vial in total. The plastic tube with the collected supernatants was afterwards dried in a vacuum centrifuge (Concentrator plus, Eppendorf, Hamburg, Germany) until all the $\mathrm{MeOH}$ had evaporated. The plastic tubes were stored in the freezer $\left(-20^{\circ} \mathrm{C}\right)$ until HPLC analysis, and the Precellys vials which contained the extraction residues were air-dried and stored at $-20^{\circ} \mathrm{C}$ until analysis of $\mathrm{MeOH}$-insoluble condensed tannins.

\section{HPLC analysis}

The low molecular weight phenolics were identified and quantified using HPLC. We removed the frozen extracts from the freezer and allowed them to thaw before adding $200 \mu \mathrm{L} \mathrm{MeOH}$ to each tube. The tubes were put in an ultrasound bath (mod. no. USC200TH, VWR International LLC, Randor, US) until the dried extract dissolved. $200 \mu \mathrm{L}$ ultrapure water (USF ELGA Maxima HPLC; Veolia Water Technologies, Saint-Maurice, France) was then added to the tube. The liquid was then poured into Eppendorf vials and centrifuged for $3 \mathrm{~min}$ at 15,000 rpm. We transferred the supernatant into a HPLC vial using a Pasteur pipette, and analyzed it using a HPLC system (Agilent 1200 series, Agilent Technologies Inc., Santa Clara, USA) comprised of a G1379B degasser, a G1312A binary pump, a G1329 autosampler, a G1316A thermoregulated column heater, and a G1315D diode array detector. The mobile phases were methanol (B-solution) and a solution of $5 \mathrm{~mL}$ orthophosphoric acid $30 \mathrm{~mL}$ tetrahydrofuran diluted to $2 \mathrm{~L}$ using ultrapure water (A-solution), which eluted the samples using the same gradient as in Nybakken et al. (2012) with an injection volume of $20 \mu \mathrm{L}$. The stationary phase was a Thermo Scientific column (Thermo Fisher Scientific Inc., Waltham, USA) which has a $50 \times 4.6 \mathrm{~mm}$ internal diameter and filled with $3 \mu \mathrm{m}$ ODS Hypersil particles. The absorption spectra at $320 \mathrm{~nm}$, along with respective retention times, and earlier runs of the Norwegian provenance on UHPLC-MS-QTOF (unpublished data) were used to identify the chemical compounds. Concentrations were calculated by use of response factors of commercial standards.

\section{Condensed tannins}

Concentrations of both $\mathrm{MeOH}$-soluble and $\mathrm{MeOH}$-insoluble CTs were identified using the acid butanol assay for proanthocyanidins described in Hagerman (2002). The HPLC vials were removed from the autosampler maximum $48 \mathrm{~h}$ after analysis and from these $50-100 \mu \mathrm{L}$ were used to determine the amounts of $\mathrm{MeOH}$-soluble CTs. The amount of $\mathrm{MeOH}$-insoluble CTs was analyzed from the residues left after the extraction process. The samples were put in $10 \mathrm{~mL}$ glass tubes along with enough $\mathrm{MeOH}$ to equal $0.5 \mathrm{~mL}$ in total $(0.5 \mathrm{~mL} \mathrm{MeOH}$ regardless for $\mathrm{MeOH}$-insoluble tannins), then further mixed with $3 \mathrm{~mL}$ butyric acid (95\% butanol, 5\% hydrochloric acid), and $100 \mu \mathrm{L}$ iron reagent ( 2 M HCL with $2 \%$ ferric ammonium sulfate). The glass tubes were properly sealed, mixed, and placed in boiling water for $50 \mathrm{~min}$. Duplicate samples were prepared when extract amounts were allowed. After cooling, the light absorption at $550 \mathrm{~nm}$ was determined using a spectrophotometer (UV-1800; Shimadzu Corp., Kyoto, Japan). The average between duplicate samples was used as one data value. Purified tannins from spruce needles were used as standards to calculate concentrations.

\section{Data analyses}

The individual compounds were first grouped into three groups: chlorogenic acid derivatives, quercetin 
3-glycosides and kaempferol 3-glycosides. The quercetin 3-glycosides and kaempferol 3-glycosides were further grouped into total flavonoids. We also analyzed all low molecular weight phenols as one group. One compound was hence categorized into more than one group.

We developed linear mixed-effects models using the R-package «lme4» (Bates et al. 2015). The fixed effects were year, location and provenance and the random effects were row and plant number, to control for a possible effect of plant placement on phenolic content. The models were tested for significance in the R-package «lmerTest» (Kuznetsova et al. 2017). To check if the condition homogeneity of residuals was fulfilled, the residuals were plotted on a qq-plot. If this condition was violated, the data was log-transformed. To identify which groups differed significantly from other groups, the R-package «emmeans» was used (Lenth 2020). For the grouped models, $R^{2}$ values for fixed effects only were calculated according to Nakagawa and Schielzeth (2013) using the «r.squaredGLMM» function from the package «MuMIn» (Barton 2019). We developed separate models using only provenance, year or growing location to quantify how much of the variation in phenolic compound concentration was explained by provenance, year and location separately and combined.

To depict the composition of phenolic compounds, we used non-metric multidimensional scaling (NMDS) on the basis of a Bray-Curtis distance matrix, using the metaMDS function in the R package «vegan» (Oksanen et al. 2019). We used three dimensions which yielded satisfactory low tress values, but only the two first axes were printed. Further, we performed a PERMANOVA with a Bray-Curtis distance matrix and 999 permutations, using the adonis2 function in the R package «vegan», to test for the effect of year, location and provenance (and their interactions) on the composition of phenolic compounds.

All data analyses were performed using the statistical programming language $\mathrm{R}$, version 3.6.1 ( $\mathrm{R}$ core team 2019).

\section{Results}

The total amount of phenolic compounds (condensed tannins + low molecular weight phenols) in beech leaves varied between 79.2 and $432 \mathrm{mg} \mathrm{g}^{-1}$ dry weight. We identified in total 19 low molecular weight phenolic compounds, but also analyzed the summed concentrations of different phenolic groups (note that one compound may fit into multiple groups). The explanatory power of the complete mixed linear model was about $50 \%$ for low molecular weight phenolics as a group, and about $15 \%$ for the condensed tannins (Table 3). Concentrations of all individual compounds per provenance, growing location and sampling year may be found in the supplementary materials (Tables S1-S6).

\section{Effect of location and provenance}

The total concentration of low molecular weight phenolics differed significantly between growing locations in 2016 (Fig. 2a) but the differences were much smaller in 2017 (Fig. 2b). A general trend across all phenolic groups in 2016, except from condensed tannins (Figs. 2, 3 and 4), was that the highest concentrations were found in plants from Munkrøstad, the northernmost location. Munkrøstad had $63 \%$ higher concentration of low molecular weight phenolics than $̊$ s, and 83\% higher than Re in 2016 (88, 54 and $48 \mathrm{mg} \mathrm{g}^{-1}$, respectively, $\left.p<0.001\right)$. In contrast, there were only minor differences between locations in 2017 . On the other hand, the concentration of $\mathrm{MeOH}$-soluble condensed tannins was $13 \%$ lower in Munkrøstad than in $\AA$ s in 2016 (117 vs $\left.132 \mathrm{mg} \mathrm{g}^{-1}, p=0.016\right)$, while the $\mathrm{MeOH}-$ insoluble condensed tannins were $34 \%$ lower in Munkrøstad than in $\AA$ s and 39\% lower than in Re (9.09, 12.2 and $12.6 \mathrm{mg} \mathrm{g}^{-1}$, respectively, $\left.p<0.001\right)$. In contrast, Munkrøstad had a significantly higher concentration of MeOH-soluble condensed tannins than $\AA$ s and Re in 2017 [114, 94.9 and $98.0 \mathrm{mg} \mathrm{g}^{-1}$, respectively, $p=0.008$ (Munkrøstad-Ås) and $p<0.001$ (Munkrøstad-Re)]. The concentration of $\mathrm{MeOH}$-insoluble condensed tannins was significantly higher in Munkrøstad and Ås than in Re in
Table $3 R^{2}$ values (variance explained by the fixed effects) from r.squaredGLMM function from the R package MuMIn performed on the grouped models, incorporating each explanatory variable separately and all together (whole model)

\begin{tabular}{llrrl}
\hline Compound & Provenance & Year & Location & Whole model \\
\hline MeOH-insoluble condensed tannins & $0.31 \%$ & $2.88 \%$ & $3.17 \%$ & $23.20 \%$ \\
MeOH-soluble condensed tannins & $1.28 \%$ & $2.95 \%$ & $1.27 \%$ & $15.54 \%$ \\
Low molecular weight phenols & $0.77 \%$ & $30.59 \%$ & $5.04 \%$ & $50.25 \%$ \\
Chlorogenic acid derivatives & $2.19 \%$ & $2.51 \%$ & $11.81 \%$ & $24.23 \%$ \\
Quercetin 3-glycosides & $4.37 \%$ & $26.13 \%$ & $1.94 \%$ & $50.25 \%$ \\
Kaempferol 3-glycosides & $0.54 \%$ & $43.00 \%$ & $1.73 \%$ & $54.88 \%$ \\
Total flavonoids & $2.22 \%$ & $38.83 \%$ & $1.91 \%$ & $53.99 \%$ \\
\hline
\end{tabular}

The models were developed for groups of $\mathrm{i}$ phenolic compounds in beech seedlings 

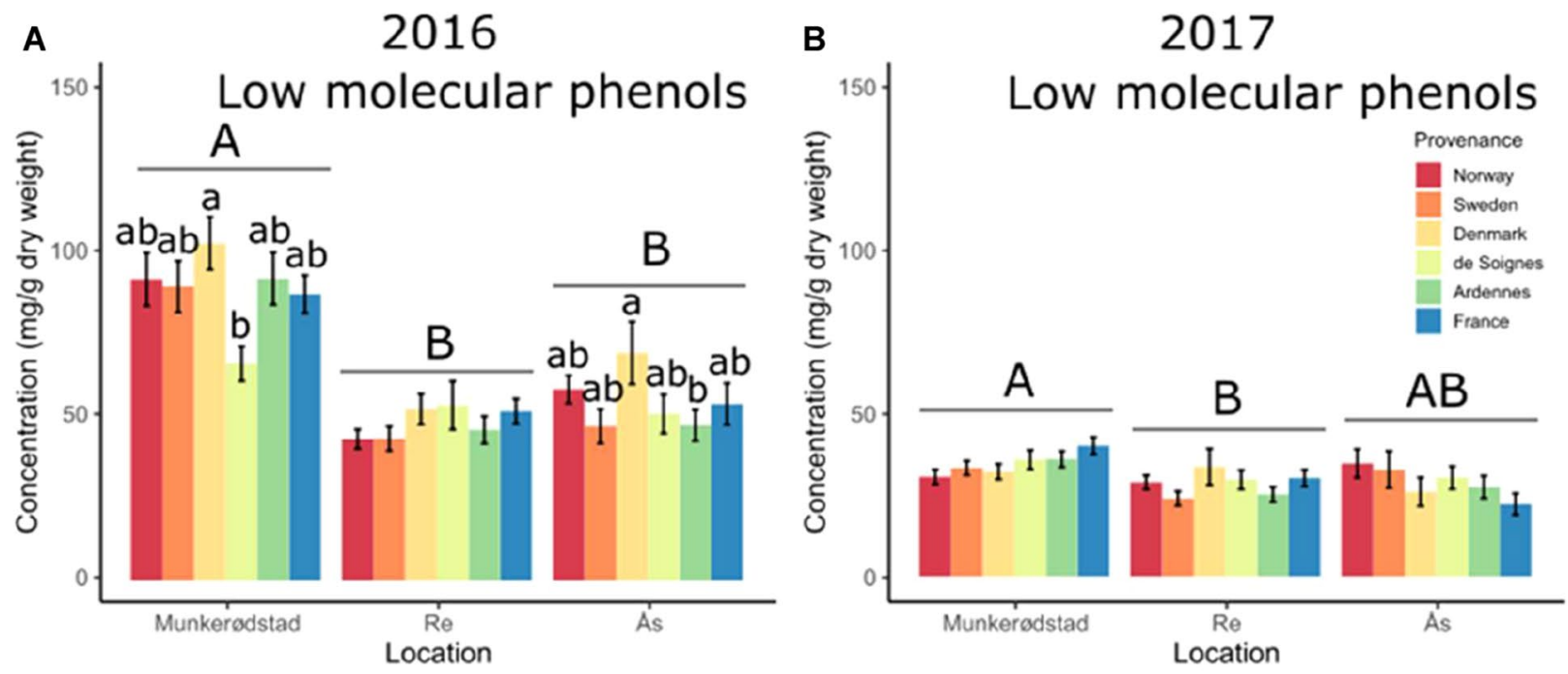

C

D

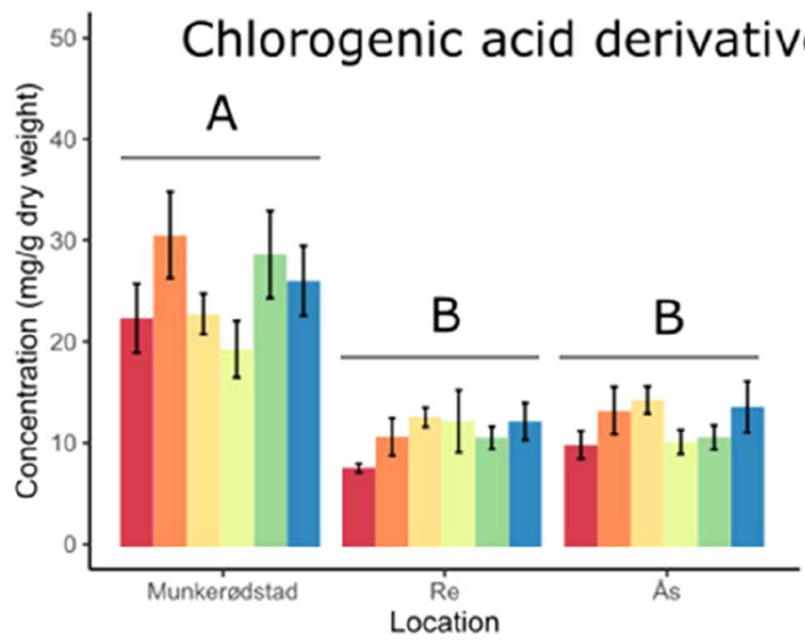

Fig. 2 Variation in total low molecular weight phenols and the subgroup chlorogenic acid derivatives in beech seedling leaves between growing location, provenances and years. Colors designate provenance, ordered from north to south. Data from 2016 is shown on the left (A and C) and data from 2017 on the right (B and D). Error bars depict the standard error of the mean. Capital letters above the

the same year $\left[14.9,13.5\right.$ and $7.98 \mathrm{mg} \mathrm{g}^{-1}$, respectively, $p<0.001$ (both)].

However, growing location explained only $5 \%$ of the variation in total low molecular weight phenols (Table 3 ). In the mixed linear models, growing location was highly significant for most compounds with a few exceptions (Table 4). The interaction term between year and location was significant in all models except for dicoumaroylastragallin 2 (Table 4), as many compounds exhibited significant differences between locations in 2016, but not in 2017. The interaction factor between year, location and provenance were non-significant in all models.

The provenances differed significantly from each other only in certain compounds and growing locations (e.g., Fig. 3e). There was no clear trend among the provenances, but Denmark stood out as the provenance with the highest concentration of low molecular weight phenolics in many cases, whereas the two Belgian provenances often had the lowest concentration (Figs. 3, 4). In the mixed linear models, provenance was significant in 17 out of 26 compounds or groups of compounds (Table 4), but often only within one growing location. Provenance only explained $0.77 \%$ of the variance in total low molecular weight phenolics (Table 3). 


\section{Effect of year}

The mean concentration of total low molecular weight phenolics was twice as high in $2016\left(63.8 \mathrm{mg} \mathrm{g}^{-1}\right)$ compared to 2017 (30.6 $\mathrm{mg} \mathrm{g}^{-1}, p<0.001$ ). The absolute differences between growing locations were also smaller in 2017 , whereas the relative differences showed no clear trend. The average concentration of $\mathrm{MeOH}$-soluble condensed tannins across provenances and planting locations also decreased from 2016 to 2017, from 122 to $10 \mathrm{mg} \mathrm{g}^{-1}(p<0.001)$. There was no significant decrease in $\mathrm{MeOH}$-soluble condensed tannins between the years in Munkrøstad $(p=0.360)$, but the amount of MeOH-soluble condensed tannins in $\AA$ s decreased from 2016 to 2017 ( $p<0.001)$. There was no significant change in $\mathrm{MeOH}$-insoluble condensed tannins between the years $\left(11.1 \mathrm{mg} \mathrm{g}^{-1}\right.$ in 2016 and $13.0 \mathrm{mg} \mathrm{g}^{-1}$ in 2017, $p=0.433$ ).

Year was the variable which explained the largest part of the variance in low molecular weight phenols, both in total and by group (Table 3 ) and was also a highly significant variable in the linear mixed models of almost all phenolic compounds (Table 4). Year explained almost $31 \%$ of the variance in the concentration of low molecular weight phenolics, but only $3 \%$ of the variance in $\mathrm{MeOH}$-soluble condensed tannins (Table 3). There was also a large variation in the explanatory power of year between the groups of low molecular weight phenolics. Whereas year explained $43 \%$ of the variation in kaempferol 3-glycosides, the corresponding number for chlorogenic acid derivatives was only $2.5 \%$ (Table 3).

\section{Phenolic composition}

When depicted in an NMDS, the composition of phenolic compounds varied significantly between sampling year, location and provenance (Table 5, Fig. 5). The NMDS confirms the patterns shown by the GLMM, showing the highest explanatory power of sampling year, followed by growing location and provenance. The separation in compound composition between years along the first axis was partly driven by higher concentrations of quercetin 3-glycosides, most kaempferol 3-glycosides, and those compounds categorized as "other flavonoids" (mono- and di-coumaroylastragallins and dihydroquercetin) in 2016. While chlorogenic acids generally were found in higher concentrations in 2016, some derivatives were more associated with the sampling in 2017. The composition of phenolic compounds was distinctly different between the three sites, where Re was intermediate. The six provenances were separated along the second axis where the compound composition in provenances from Norway and Denmark were distinctly different from the others. This was primarily driven by some chlorogenic acid derivatives generally having lower concentrations in provenances from Norway and Denmark, while the concentrations of "other flavonoids" often were higher.

\section{Discussion}

Our main aim was to explore and quantify the factors influencing phenolic defense in beech seedlings. Sampling year was the factor explaining most of the variation in low molecular weight phenolics. Six provenances were tested, representing a large variety of geographical origins, but we mostly found only small differences between them. The highest phenolic concentrations were found in the northernmost growing location, and the growing location explained more of the variation in foliar phenolics than provenance in this experiment. Our finding that growing location (environment) affected the foliar phenolics more than the provenance (genetic background) contrasts with previous findings in beech.

\section{Variation between growing locations}

The northernmost growing location (Munkrøstad) had the highest concentration of low molecular weight phenolics after one growing season in the field, and one year later this was still true for chlorogenic acids. With regards to condensed tannins, these were highest in the south after the first field season, while Munkrøstad had highest concentrations in 2017. Munkrøstad has lower mean annual temperature than Ås and Re, and possibly somewhat less fertile soils. Both factors may explain our results, as several previous studies have concluded that foliar phenolic concentration depends on environmental variables. Pahlsson (1989) reported that the concentration of foliar phenolics increased in beeches deficient in several mineral nutrients. Generally, foliar phenolics and nitrogen availability is negatively correlated (Koricheva et al. 1998). Bussotti et al. (1998) also found more foliar phenolics, mainly tannins, at high elevations in mature beeches. As these were natural beech populations, the populations differed not only in growing site, but also in genetic background. By contrast, Zimmer et al. (2015) found that the total concentration of foliar phenolics depended more on provenance than on environment but hypothesized that the difference in concentration of individual compounds was mainly due to the temperature difference between the growing sites. Covelo and Gallardo (2001) found that growing site explained a large part of foliage phenolics variation in oak seedlings. However, in their study, different growing site also meant a difference in light availability and genetic background. To our knowledge, no experimental study has so far looked at the effect of temperature on foliar phenolics in beech, but there are several publications on other tree species, as reviewed by Julkunen-Tiitto et al. (2015). In a 
A 2016

Kaempferol 3-glycosides

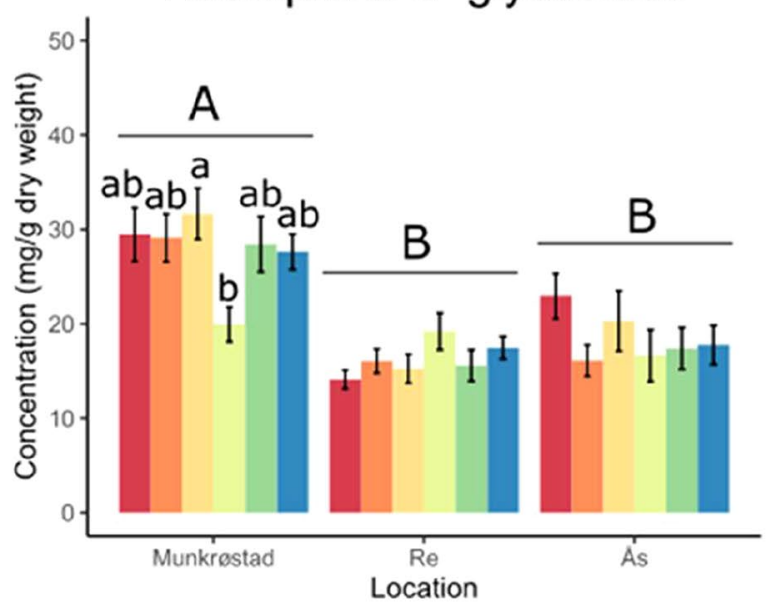

C

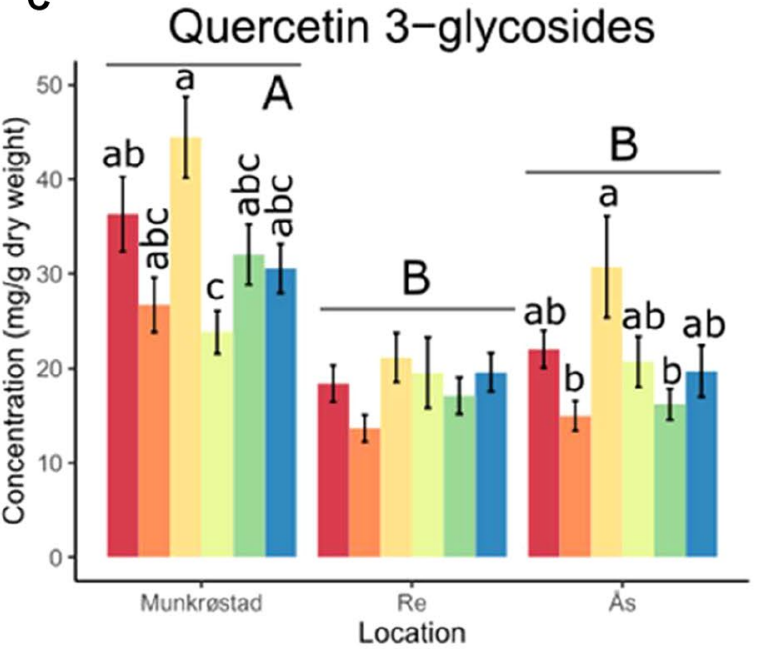

E

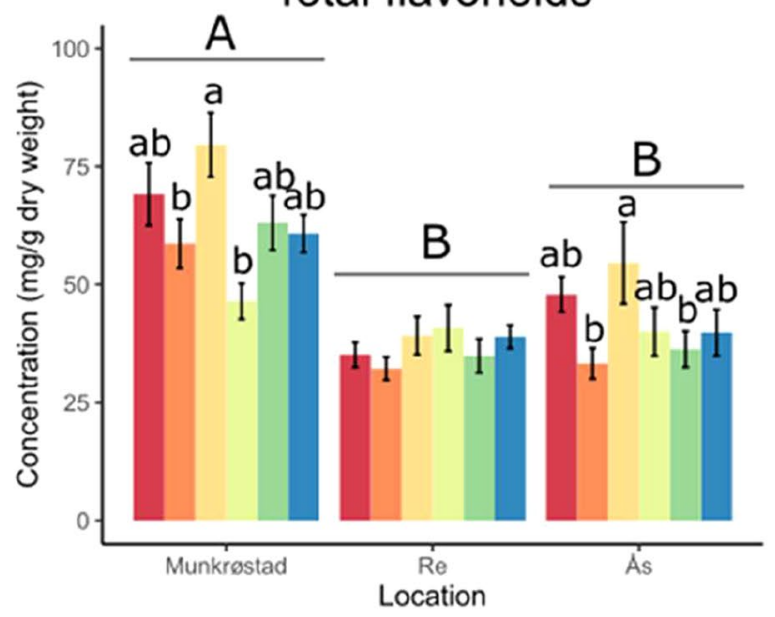

2017

Kaempferol 3-glycosides

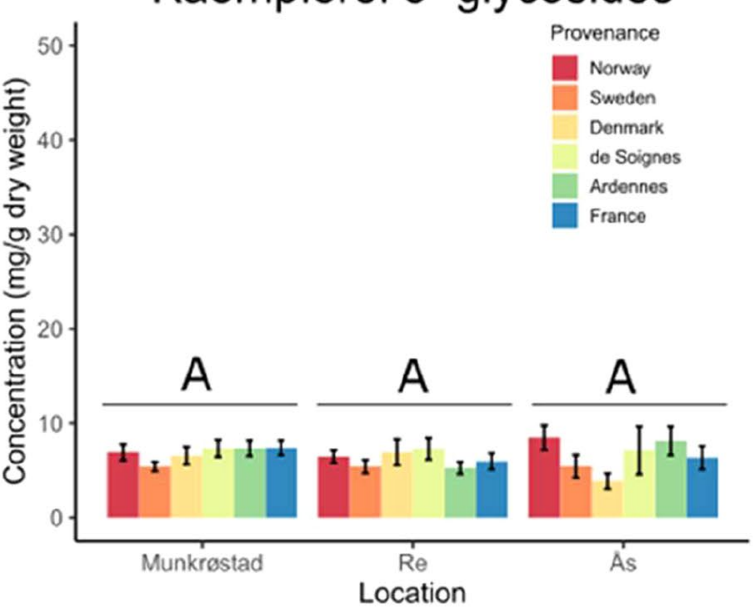

D

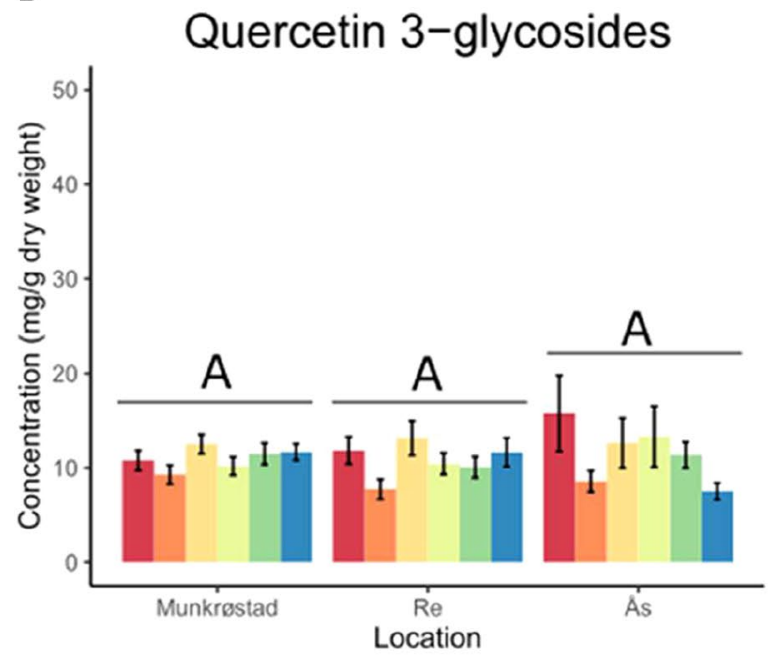

$\mathbf{F}$

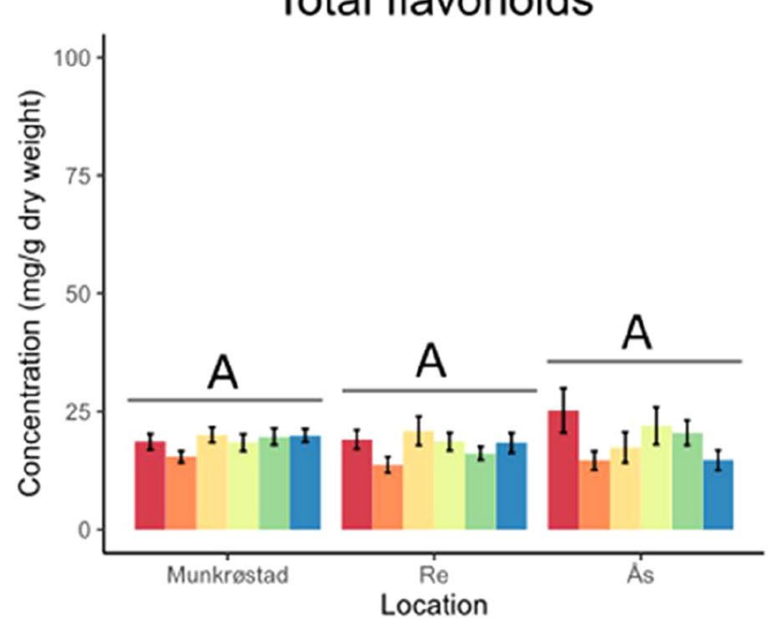


4Fig. 3 Variation in kaempferol 3-glycosides, quercetin 3-glycosides and total flavonoids (kaempferol 3-glycosides + quercetin 3-glycosides) in beech seedling leaves between growing location, provenances and years. Colors designate provenance, ordered from north to south. Data from 2016 is shown on the left (A, C and E) and data from 2017 on the right (B, D and F). Error bars depict the standard error of the mean. Capital letters above the horizontal lines indicate statistical significance $(p<0.05)$ between the growing location. Lowercase letters show statistical significance $(p<0.05)$ between provenances within a growing location. If no provenances were statistically significant, no letters

study on dark-leaved willow (Salix myrsinifolia), Nybakken et al. (2012) found a decrease in foliar phenolics, including tannins, with increasing temperature. The decrease of phenolics at higher temperatures is likely caused by temperaturedependent regulation of genes involved in the phenol biosynthesis, as well as faster degradation of kaempferol- and quercetin glycosides (Escobar-Bravo et al. 2017; Olsen et al. 2009). Also, in spruce seedling needles, the elevated temperature decreased the concentration of low molecular weight phenolics, but not condensed tannins (Virjamo et al. 2014). These studies, which all measured phenolics towards the end of the growing season like we did, indicate that lower temperatures result in higher concentrations of low molecular weight phenolics, and as such supports lower temperature as an explanation for the northernmost location having the highest phenolic concentrations in our study.

\section{Variation between provenances}

We observed differences in concentrations of some phenolic compounds between some provenances, which points towards local adaptation (Robson et al. 2012). However, it should be noted that differences in treatments of seeds and variations in early growth conditions of the plants from the different provenances may have affected our results. Beech has high intraspecific genetic variability, and genetic differences between provenances exist (Konnert 1995; Konnert and Ruetz 2001). The similar composition of phenolic compounds in Danish and Norwegian provenances supports the suggestion by Myking et al. (2011) that the Norwegian population are of Danish origin.

The provenances in this experiment originated from a range of climates, which may require different levels and composition of constitutive chemical defense. However, beech also exhibits phenotypic plasticity (Bolte et al. 2007; Gárate-Escamilla et al. 2019), which should decrease phenotypic differences between provenances when grown in a common garden. Common gardens are used to quantify the genetic basis of traits, as the effect of different environments is minimized (de Villemereuil et al. 2016). Hence, common gardens are valuable to quantify genetic differences between provenances. Some tree species have shown significant differences in chemical defense between provenances in common gardens, e.g. lodgepole pine (Wallis et al. 2010) and ash (Enderle et al. 2013). To our knowledge, only Zimmer et al. (2015) and Aranda et al. (2017) have quantified intraspecific variation in phenolic defense in beech in a common garden setup. Zimmer et al. (2015) found that provenance explained $25 \%$ of the total phenolic content in beech, while Aranda et al. (2017) also found a significant effect of provenance on foliar phenolics in beech, which was larger than the effect of water stress. On the other hand, Baldwin et al. (1987) found no significant provenance effect on the total phenolic content in yellow birch (Betula allegheniensis) and sugar maple (Acer saccharum), and only one provenance showed significantly higher levels of condensed tannins. Deepak et al. (2018) found that for silver birch (Betula pendula) the variation as explained by provenance differed between individual phenolic compounds. In summary, our study supports previous suggestions that Norwegian beech provenances have Danish origin and shows that these two provenances differ in phenolic composition from the others tested here. However, provenance as such explained a relatively low amount of the variation in phenolics between plants.

\section{Variation between years}

We found a large reduction in low molecular phenolics, and a shift in the composition of compounds, from the first to the second year in the field. Condensed tannins, on the other hand, increased. Differences in weather and aging of the seedlings can both cause variation in phenolics between years, while stress due to planting and establishment may also have been important. Effects of plant age or ontogenetic stage on chemical defense is rather little studied, but in a meta-analyses Barton and Koricheva (2010) found little variation in total chemical defense throughout the juvenile phase of woody plants. Nissinen et al. (2018) reported no change in foliar phenol concentration in Salix myrsinifolia individuals over a 7-year period. In European aspen (Poulus tremula), however, flavonoids and phenolic acids decreased, while condensed tannins increased as the plants changed from one ontogenetic stage to another (Nissinen et al. 2017). Wam et al. (2017) correspondingly observed a decrease in foliar low molecular weight phenols and an increase in condensed tannins with age in young birches. It is important to note, however, that patterns in defensive chemistry probably also may vary with the life history strategy of species. For example, pioneers, like willow and birch, have a faster ontogenetic development/aging than late successional species like beech.

Reduction in environmental stress may also be an explanation for the change in defensive levels from the first to the second year. Plants in Munkrøstad, which were planted 


\section{A 2016 $\mathrm{MeOH}-$ soluble tannins}

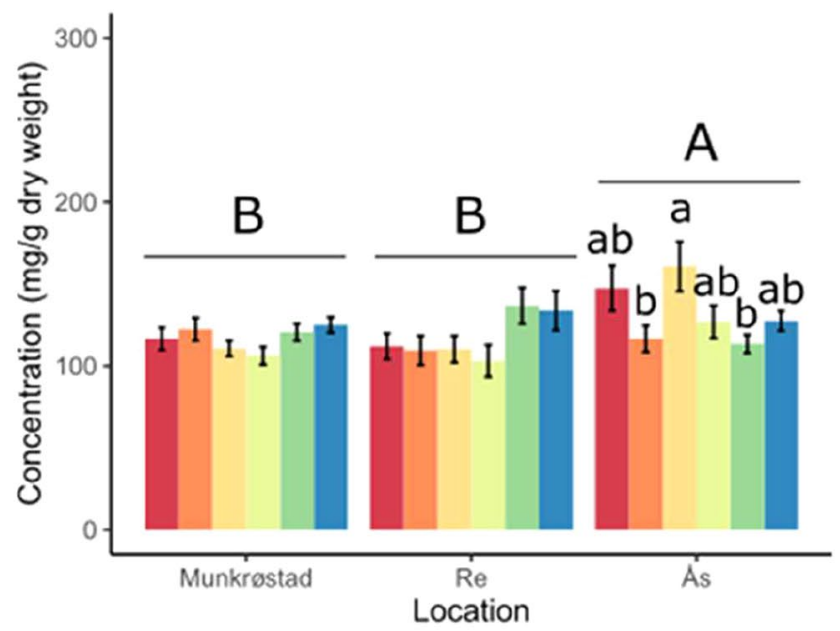

C

\section{$\mathrm{MeOH}$-insoluble tannins}

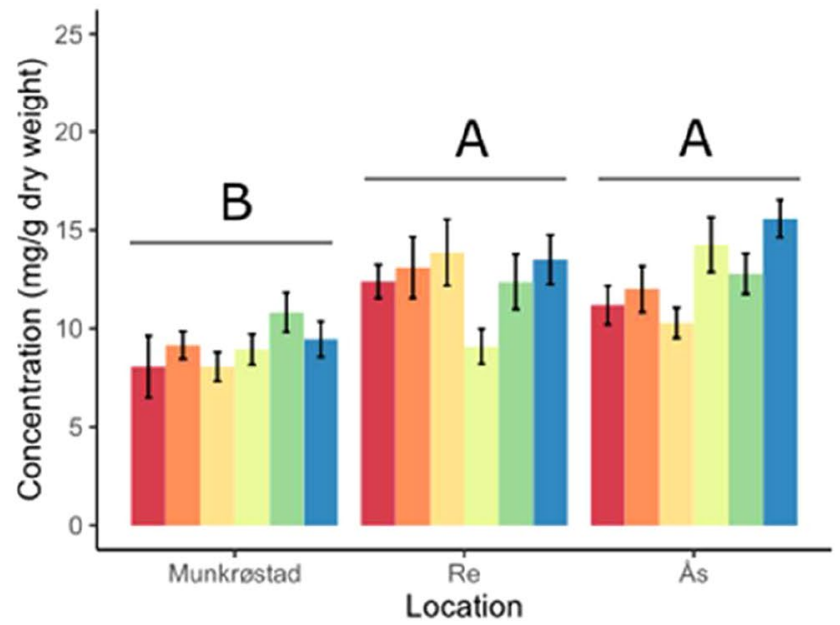

Fig. 4 Variation in $\mathrm{MeOH}$-soluble and $\mathrm{MeOH}$-insoluble condensed tannins in beech seedling leaves between growing location, provenances and years. Note the difference in scale between MeOHsoluble and insoluble condensed tannins. Colors designate provenance, ordered from north to south. Data from 2016 is shown on the left (A and C) and data from 2017 on the right (B and D). Error bars depict the standard error of the mean. Capital letters above the horizontal
B 2017 $\mathrm{MeOH}-$ soluble tannins

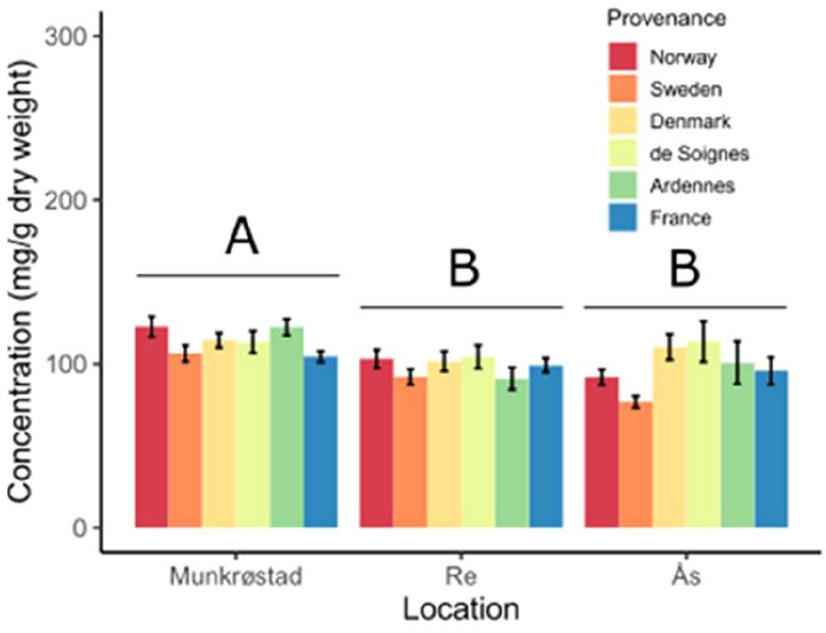

\section{MeOH-insoluble tannins}

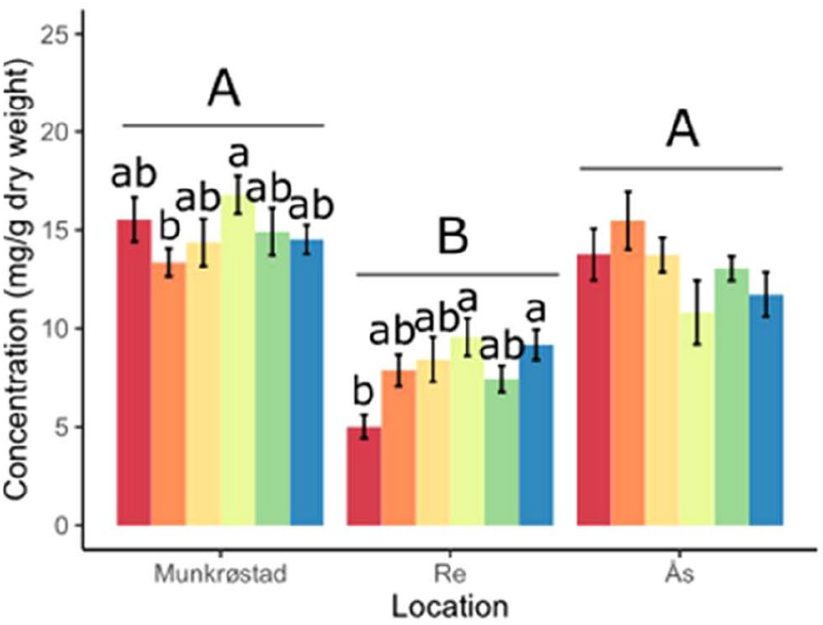

lines indicate statistical significance $(p<0.05)$ between the growing location. Lowercase letters show statistical significance $(p<0.05)$ between provenances within a growing location. If no provenances were statistically significant, no letters are shown. Statistical significance was calculated using ANOVA on log-transformed linear mixed effects models in $\mathrm{R}$

of seedlings in Munkrøstad in 2016, as well as the large decrease in phenols in these plants between 2016 and 2017. Even for established seedlings, there might be a carry-over effect of the planting stress for instance due to nutrient limitations (Grossnickle 2005), which may cause a higher stress level over time in seedlings after planting. In conclusion, the planting stress was likely higher in Munkrøstad because of less favorable soil conditions and later planting, which may 
Table 4 ANOVA output of the linear mixed effects models of variation in phenolic composition in beech seedling leaves between growing locations, provenances and years

\begin{tabular}{|c|c|c|c|c|c|c|c|c|}
\hline & Compound & Provenance & Year & Location & $\mathrm{P}: \mathrm{Y}$ & P:L & Y:L & P:Y:L \\
\hline & $\begin{array}{l}\text { Low molecular weight } \\
\text { phenols }\end{array}$ & $1.12(0.348)$ & $372.06(<0.001)$ & $55.28(<0.001)$ & $1.53(0.178)$ & $1.61(0.100)$ & $18.26(<0.001)$ & $1.52(0.129)$ \\
\hline & $\begin{array}{l}\text { Chlorogenic acid deriva- } \\
\text { tives }\end{array}$ & $2.64(0.023)$ & $27.69(<0.001)$ & $71.49(<0.001)$ & $2.19(0.054)$ & $1.65(<0.001)$ & $9.92(<0.001)$ & $1.45(0.156)$ \\
\hline & Quercetin 3-glycosides & $6.99(<0.001)$ & $237.72(<0.001)$ & $13.23(<0.001)$ & $0.84(0.518)$ & $1.05(0.401)$ & $20.29(<0.001)$ & $0.66(0.760)$ \\
\hline & Kaempferol 3-glycosides & $1.35(0.242)$ & $626.81(<0.001)$ & $14.79(<0.001)$ & $2.11(0.063)$ & $1.39(0.181)$ & $12.69(<0.001)$ & $1.25(0.253)$ \\
\hline & Total flavonoids & 3.91(0.002) & 498.07( $<0.001)$ & $17.76(<0.001)$ & $1.42(0.213)$ & $1.35(0.199)$ & $19.84(<0.001)$ & $0.83(0.599)$ \\
\hline 1 & Neochlorogenic acid & $4.47(<0.001)$ & $17.31(<0.001)$ & $9.79(<0.001)$ & $0.83(0.525)$ & $0.69(0.738)$ & $15.34(<0.001)$ & $0.52(0.873)$ \\
\hline 2 & Chlorogenic acid der. 1 & $1.37(0.233)$ & 430.07 $(<0.001)$ & 3.02(0.049) & 3.08(0.009) & 2.41(0.008) & $3.62(0.027)$ & $0.78(0.644)$ \\
\hline 3 & Chlorogenic acid der. 2 & $0.19(0.968)$ & $342.54(<0.001)$ & $6.28(0.002)$ & 2.42(0.035) & $0.40(0.946)$ & $14.78(<0.001)$ & $0.77(0.655)$ \\
\hline 4 & Chlorogenic acid der. 3 & $3.62(0.003)$ & $0.05(0.826)$ & $0.52(0.592)$ & $2.98(0.011)$ & $0.87(0.563)$ & $10.21(<0.001)$ & $0.99(0.446)$ \\
\hline 5 & Chlorogenic acid & $2.17(0.056)$ & $13.49(<0.001)$ & $39.49(<0.001)$ & $1.06(0.379)$ & $1.54(0.120)$ & $0.66(0.520)$ & $0.61(0.803)$ \\
\hline 6 & Chlorogenic acid der. 4 & $4.03(0.001)$ & $133.93(<0.001)$ & $24.82(<0.001)$ & $1.51(0.184)$ & $1.39(0.179)$ & $32.06(<0.001)$ & $1.21(0.280)$ \\
\hline 7 & Dihydroquercetin der. 1 & $6.06(<0.001)$ & $168.76(<0.001)$ & $0.25(0.777)$ & $2.47(0.031)$ & $0.56(0.845)$ & 3.77(0.024) & $0.47(0.907)$ \\
\hline 8 & Quercetin 3-glycoside 1 & $6.49(<0.001)$ & $293.79(<0.001)$ & $6.87(0.001)$ & $4.40(<0.001)$ & $1.55(0.120)$ & $16.90(<0.001)$ & $1.47(0.147)$ \\
\hline 9 & Quercetin 3-glycoside 2 & $3.56(0.004)$ & $182.21(<0.001)$ & $5.82(0.003)$ & $1.10(0.360)$ & $0.90(0.532)$ & $7.16(<0.001)$ & $0.96(0.476)$ \\
\hline 10 & Quercetin 3-glycoside 3 & $4.30(<0.001)$ & $442.24(<0.001)$ & $14.15(<0.001)$ & $1.87(0.097)$ & $1.33(0.210)$ & $7.80(<0.001)$ & $1.39(0.182)$ \\
\hline 11 & Chlorogenic acid der. 5 & 4.10(0.001) & $516.61(<0.001)$ & $13.72(<0.001)$ & $2.90(0.013)$ & $1.05(0.402)$ & 4.04(0.018) & $0.97(0.467)$ \\
\hline 12 & Kaempferol 3-glycoside 1 & $2.56(0.026)$ & $224.50(<0.001)$ & $7.04(<0.001)$ & $1.16(0.328)$ & $0.60(0.812)$ & $28.45(<0.001)$ & $0.63(0.791)$ \\
\hline 13 & Kaempferol 3-glycoside 2 & $1.98(0.080)$ & $474.44(<0.001)$ & $26.51(<0.001)$ & $2.22(0.050)$ & $1.51(0.132)$ & $3.50(0.031)$ & $1.54(0.121)$ \\
\hline 14 & Chlorogenic acid der. 6 & $7.24(<0.001)$ & $35.35(<0.001)$ & $18.10(<0.001)$ & $3.39(0.005)$ & $1.62(0.096)$ & $6.62(0.001)$ & $1.78(0.060)$ \\
\hline 15 & Kaempferol 3-glycoside 3 & $3.47(0.004)$ & $34.31(<0.001)$ & $6.00(0.003)$ & $7.72(<0.001)$ & $1.56(0.115)$ & $29.25(<0.001)$ & $1.50(0.136)$ \\
\hline 16 & Kaempferol 3-glycoside 4 & $1.98(0.080)$ & $486.52(<0.001)$ & $31.67(<0.001)$ & $3.22(0.007)$ & $1.60(0.103)$ & $36.92(<0.001)$ & $0.93(0.501)$ \\
\hline 17 & Monocoumaroylastragallin & $8.02(<0.001)$ & $185.40(<0.001)$ & $10.96(<0.001)$ & $1.64(0.146)$ & $0.86(0.574)$ & 4.21(0.015) & $0.94(0.494)$ \\
\hline 18 & Dicoumaroylastragallin 1 & $2.23(0.05)$ & $167.71(<0.001)$ & $0.62(0.540)$ & $1.83(0.105)$ & $1.05(0.397)$ & $2.08(0.125)$ & $1.22(0.272)$ \\
\hline 19 & Dicoumaroylastragallin 2 & $5.66(<0.001)$ & $63.74(<0.001)$ & $1.72(0.180)$ & $0.53(0.751)$ & $0.32(0.977)$ & $0.63(0.531)$ & $0.63(0.788)$ \\
\hline 20 & $\begin{array}{l}\text { MeOH-soluble condensed } \\
\text { tannins }\end{array}$ & $1.51(0.185)$ & $0.65(0.420)$ & $12.15(<0.001)$ & $0.80(0.805)$ & $0.66(0.655)$ & $48.88(<0.001)$ & $2.61(0.004)$ \\
\hline 21 & $\begin{array}{l}\text { MeOH-insoluble con- } \\
\text { densed tannins }\end{array}$ & $2.49(0.030)$ & $39.13(<0.001)$ & $6.26(0.002)$ & $1.85(0.101)$ & $1.95(0.036)$ & $10.23(<0.001)$ & $1.62(0.097)$ \\
\hline
\end{tabular}

$F$-values ( $p$ values). Low molecular weight phenols, chlorogenic acid derivatives, quercetin 3-glycosides, kaempferol 3-glycosides and total flavonoids are composed of data from the individual phenolic compounds numbered 1-21. Statistically significant results $(p<0.05)$ are printed in bold. $P: Y$ stands for the interaction between provenance and year

Table 5 Permutational multivariate analyses of variance (PERMANOVA; using 999 permutations) testing for the effect of year, location and provenance on the composition of phenolic compounds in beech leaves

\begin{tabular}{llr}
\hline & Df & \multicolumn{1}{c}{$F(P)$} \\
\hline Year & 1,675 & $145.9(<0.001)$ \\
Location & 2,675 & $19.7(<0.001)$ \\
Provenance & 5,675 & $3.4(<0.001)$ \\
$\mathrm{Y} * \mathrm{~L}$ & 2,675 & $17.8(<0.001)$ \\
$\mathrm{Y} * \mathrm{P}$ & 5,675 & $2.2(0.004)$ \\
$\mathrm{L} * \mathrm{P}$ & 10,675 & $2.1(0.004)$ \\
$\mathrm{Y} * \mathrm{~L} * \mathrm{P}$ & 10,675 & $1.1(0.394)$ \\
\hline
\end{tabular}

have contributed to the high phenolics level in Munkrøstad in the first year.

The variation between years seems to be unrelated to climatic differences. Although the mean temperature in Munkrøstad during the growing period stayed the same in 2016 and 2017, the seedlings growing in Munkrøstad had the largest decrease in low molecular weight phenols. Most likely, the patterns observed were driven by a combination of acclimation to the growing site and aging of the seedlings.

\section{Implications}

Our results indicate that total low molecular phenolic concentration in beech seedlings depends more on the environment than on the seedling's genetic background, which 
Fig. 5 Ordination plot derived from a global non-metric multidimensional scaling (NMDS) of phenolic compounds in beech leaves from six different provenances planted at three common gardens and sampled in two different years. Crosses represent standard errors of the centroids for year (2016 and 2017), provenance (Norway [N], Sweden [S], Denmark [D], Belgium [de Soignes, BS], Belgium [Ardennes, BA] and France $[\mathrm{F}]$ ) and, in red, location of each common garden (Re, As and Munkrøstad). The colored dots represent individual phenolic compounds numbered according to Table 4 and their color denote phenolic group. Stress value indicate goodness of fit

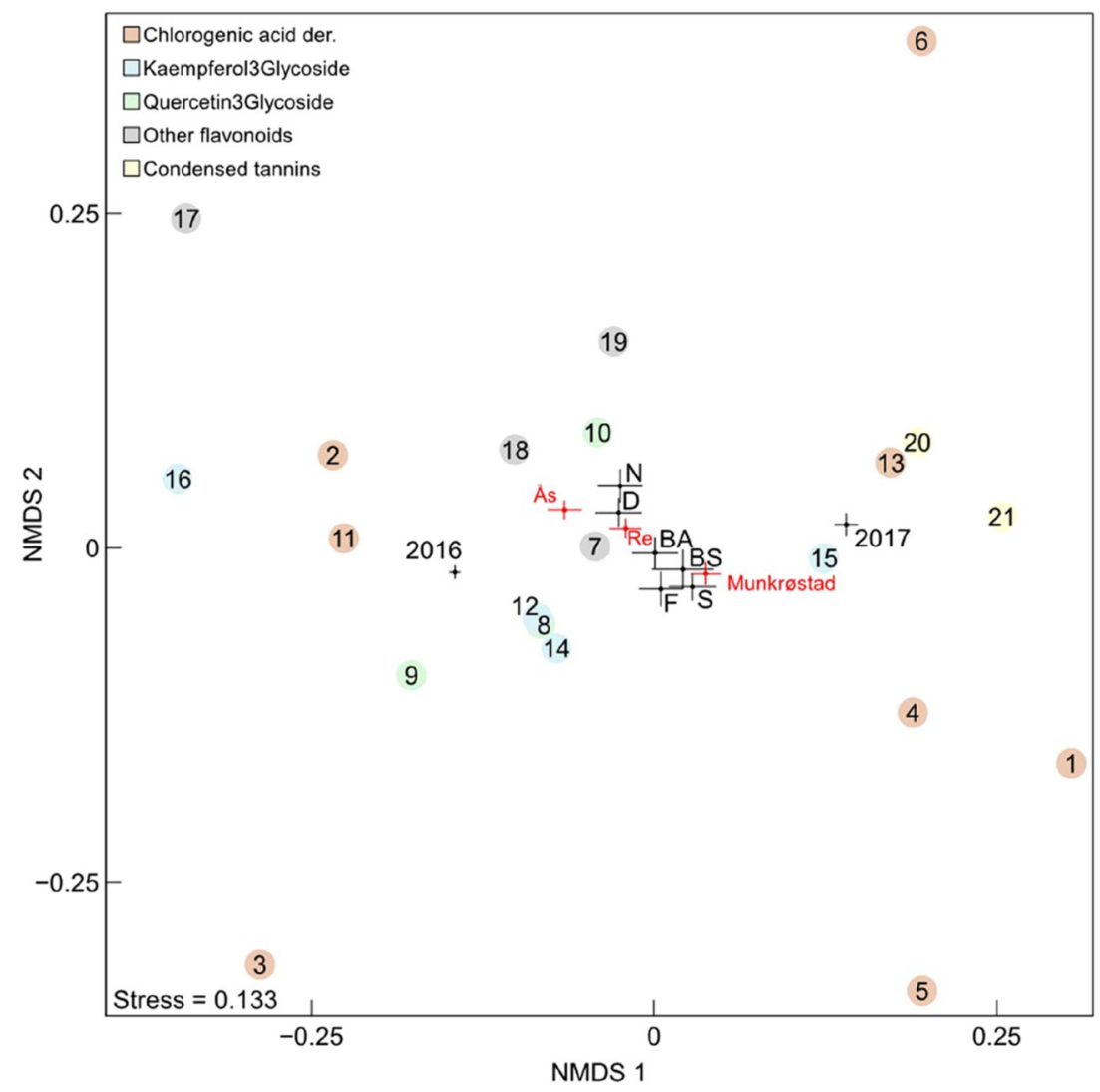

has implications for how beech reacts to climate change. Traits which responds to changes in the environment without a change in genotype, exhibit phenotypic plasticity, whereas local adaptation produces new genotypes which are better adapted to the site conditions through natural selection (Gárate-Escamilla et al. 2019). Phenotypic plasticity results in acclimation, which is a more rapid adjustment to environmental change than genetic adaptation, especially in organisms with long generation times such as beech. Global warming will cause substantial changes in environmental factors in European forests such as higher mean temperatures, more uneven precipitation patterns, higher $\mathrm{CO}_{2}$-concentration in the air and more frequent pathogen infections (IPCC 2014; La Porta et al. 2008). Beech at the edge of its range is more sensitive to climatic conditions than core populations, and it has become more sensitive over the last decades (Farahat and Linderholm 2018). It remains to be seen if the acclimation can keep up with the speed at which the climate changes. Saltré et al. (2015) did not assume it will and predicted a decrease in the distribution area of European beech by 36-61\% by 2100. The future climate, with more frequent weather extremes might cause a threat to beech populations at the northernmost distribution limits in Europe.

\section{Conclusions}

This study adds to the understanding of how genes and environment affect the chemical defense in beech seedlings. Our findings indicate that the concentration of phenolic compounds in beech leaves depends more on the environment than on the genetic background of the seedlings. Hence, changes in the environmental conditions such as changed precipitation patterns and higher temperatures will cause changes in the concentration and composition of foliar phenols in beech. However, it also indicates high phenotypic plasticity. We do not quantify the direction nor the magnitude of the change in phenols, as the experiment only went on for two years. This is also a highly complex process, which is influenced by a multitude of factors, which in part counteract each other. Furthermore, we observed a large decrease in phenolics between the first and the second year in the field, which may be attributed to decreased stress from planting and establishment on the site. This is an indication of acclimation to changes in the environment and hence phenotypic plasticity. There was also a difference in the phenolic composition between planting locations, provenances, and years, and it seems like the environment influences the phenolic composition more than the genetic background. 
Our knowledge of how the phenolic composition and concentration of phenolic defense compounds in beech relate to genetic background and environment is still incomplete, particularly as existing results are contradictory. Several common garden provenance trials exist for beech, but few of these experiments include studies of chemical defense. Sampling leaves to quantify defense chemicals from existing common gardens will minimize stress due to planting and establishment, and cut costs compared to establishing new common garden experiments. Experiments where seedlings are subjected to controlled temperatures and precipitation are also needed to untangle the effects of different climatic aspects on chemical defense in beech. We have yet to see the full extent and speed of global change, and the knowledge of how beech reacts to rapid environmental change is still insufficient for making reliable forecasts about the future fitness of the species.

Author's contribution statement J.S.S. did a large part of the laboratory work, analyzed the data, and wrote the manuscript. J.A. contributed to the statistical analyses and fieldwork and wrote the manuscript. M.H.L. planned the experiment, lead the fieldwork, and wrote the manuscript. L.N. planned the experiment, took part in fieldwork, supervised the laboratory work, and wrote the manuscript.

Supplementary Information The online version contains supplementary material available at https://doi.org/10.1007/s00468-021-02136-5.

Acknowledgements We thank the Norwegian Genetic Resource Center and The Norwegian Agriculture Agency for economical support through two grants. We are also indebted to Christian B. Strømme, Yngvild E. Ransedokken, Birgit Hagalid and Arne Steffenrem for their contribution with sampling and field work. Annie Aasen and Claus Kreibich contributed to laboratory analyses.

Funding Open access funding provided by Norwegian University of Life Sciences..

\section{Declarations}

Conflict of interest The authors declare that they have no conflicts of interest.

Open Access This article is licensed under a Creative Commons Attribution 4.0 International License, which permits use, sharing, adaptation, distribution and reproduction in any medium or format, as long as you give appropriate credit to the original author(s) and the source, provide a link to the Creative Commons licence, and indicate if changes were made. The images or other third party material in this article are included in the article's Creative Commons licence, unless indicated otherwise in a credit line to the material. If material is not included in the article's Creative Commons licence and your intended use is not permitted by statutory regulation or exceeds the permitted use, you will need to obtain permission directly from the copyright holder. To view a copy of this licence, visit http://creativecommons.org/licenses/by/4.0/.

\section{References}

Agati G, Azzarello E, Pollastri S, Tattini M (2012) Flavonoids as antioxidants in plants: location and functional significance. Plant science 196:67-76

Alkemade R, Bakkenes M, Eickhout B (2011) Towards a general relationship between climate change and biodiversity: an example for plant species in Europe. Reg Environ Change 11:143-150

Aranda I, Sánchez-Gómez D, de Miguel M, Mancha JA, Guevara MA, Cadahía E, de Simón MBF (2017) Fagus sylvatica L. provenances maintain different leaf metabolic profiles and functional response. Acta oecologica 82:1-9

Baldwin IT, Schultz JC, Ward D (1987) Patterns and sources of leaf tannin variation in yellow birch (Betula allegheniensis) and sugar maple (Acer saccharum). J Chem Ecol 13:1069-1078

Barbehenn RV, Constabel CP (2011) Tannins in plant-herbivore interactions. Phytochemistry 72:1551-1565

Barton K (2019) MuMIn: multi-model inference. R package version 1.43.15.

Barton KE, Koricheva J (2010) The ontogeny of plant defense and herbivory: characterizing general patterns using meta-analysis. Amer Natural 175(4):481-493

Bates D, Maechler M, Bolker B, Walker S (2015) Fitting linear mixed-effects models using lme4. J Stat Softw 67:1-48

Bjune AE, Helvik I, Birks HJB (2013) The Fagus sylvatica forests in the Larvik region, south-eastern Norway: their origin and history. Veg Hist Archaeobot 22:215-229

Bolte A, Czajkowski T, Kompa T (2007) The north-eastern distribution range of European beech-a review. Forestry 80:413-429. https://doi.org/10.1093/forestry/cpm028

Bradshaw RHW, Holmqvist BH, Cowling SA, Sykes MT (2000) The effects of climate change on the distribution and management of Picea abies in southern Scandinavia. Can J For Res 30:19921998. https://doi.org/10.1139/cjfr-30-12-1992

Bussotti F, Gravano E, Grossoni P, Tani C (1998) Occurrence of tannins in leaves of beech trees (Fagus sylvatica) along an ecological gradient, detected by histochemical and ultrastructural analyses. New Phytol 138:469-479. https://doi.org/10.1046/j. 1469-8137.1998.00121.x

Contreras RA, Pizarro M, Köhler H, Zamora P, Zúñiga GE (2019) UV-B shock induces photoprotective flavonoids but not antioxidant activity in Antarctic Colobanthus quitensis (Kunth) Bartl. Environ Exp Bot 159:179-190

Covelo F, Gallardo A (2001) Temporal variation in total leaf phenolics concentration of Quercus robur in forested and harvested stands in northwestern Spain. Can J Bot 79:1262-1269. https:// doi.org/10.1139/b01-109

de Villemereuil P, Gaggiotti OE, Mouterde M, Till-Bottraud I (2016) Common garden experiments in the genomic era: new perspectives and opportunities. Heredity 116:249-254

Deepak M, Lihavainen J, Keski-Saari S, Kontunen-Soppela S, Salojarvi J, Tenkanen A, Heimonen K, Oksanen E, Keinänen M (2018) Genotype- and provenance-related variation in the leaf surface secondary metabolites of silver birch. Can J For Res 48:494-505. https://doi.org/10.1139/cjfr-2017-0456

Enderle R, Peters F, Nakou A, Metzler B (2013) Temporal development of ash dieback symptoms and spatial distribution of collar rots in a provenance trial of Fraxinus excelsior. Eur J For Res 132:865-876

Escobar-Bravo R, Klinkhamer PG, Leiss KA (2017) Interactive effects of UV-B light with abiotic factors on plant growth and chemistry, and their consequences for defense against arthropod herbivores. Front Plant Sci 8:278 
Farahat E, Linderholm HW (2018) Growth-climate relationship of European beech at its northern distribution limit. Eur J For Res 137:619-629

Ganthaler A, Stöggl W, Kranner I, Mayr S (2017) Foliar phenolic compounds in Norway spruce with varying susceptibility to Chrysomyxa rhododendri: analyses of seasonal and infection-induced accumulation patterns. Front Plant Sci 8:1173

Gárate-Escamilla H, Hampe A, Vizcaíno-Palomar N, Robson TM, Benito Garzón M (2019) Range-wide variation in local adaptation and phenotypic plasticity of fitness-related traits in Fagus sylvatica and their implications under climate change. Glob Ecol Biogeogr 28:1336-1350

Geological Survey of Norway (2020) NGU Løsmassekart https://geo. ngu.no/kart/losmasse/ Accessed 30 Apr 2020.

González VT, Junttila $\mathrm{O}$, Lindgård B, Reiersen R, Trost K, Bråthen KA (2015) Batatasin-III and the allelopathic capacity of Empetrum nigrum. Nordic J Bot 33:225-231

Grossnickle SC (2005) Importance of root growth in overcoming planting stress. New For 30:273-294

Grossnickle S, Reid C (1984) Water relations of Engelmann spruce seedlings on a high-elevation mine site: an example of how reclamation techniques can alter microclimate and an edaphic conditions. Reclam Reveget Res 3:199-221

Ingels C (2015) Soils and Soil Fertility. California Farm Academy (ed.). California. pp. http://ccag-eh.ucanr.edu/files/237616.pdf.

IPCC (2014). Synthesis report. contribution of working groups I, II and III to the Fifth assessment report of the intergovernmental panel on climate change. In: Meyer, R. K. P. a. L. A. (ed.). Geneva, Switzerland: IPCC.

Julkunen-Tiitto R, Nybakken L, Randriamanana T, Virjamo V (2015) Boreal woody species resistance affected by climate change. Climate change and insect pests. CABI, Wallingford, pp 54-73

Kellomäki S, Rouvinen I, Peltola H, Strandman H, Steinbrecher R (2001) Impact of global warming on the tree species composition of boreal forests in Finland and effects on emissions of isoprenoids. Glob Change Biol 7:531-544

Konnert M (1995) Investigations on the genetic variation of beech (Fagus sylvatica L.) in Bavaria. Silvae Genetica 44:346-350

Konnert M, Ruetz W (2001) Genetic variation of beech (Fagus sylvatica $\mathrm{L}$.) provenances in an international beech provenance trial. For Genet 8:173-184

Koricheva J, Larsson S, Haukioja E, Keinänen M (1998) Regulation of woody plant secondary metabolism by resource availability: hypothesis testing by means of meta-analysis. Oikos 212-226

Kramer K, Degen B, Buschbom J, Hickler T, Thuiller W, Sykes MT, de Winter W (2010) Modelling exploration of the future of European beech (Fagus sylvatica L.) under climate change-Range, abundance, genetic diversity and adaptive response. For Ecol Manag 259:2213-2222. https://doi.org/10.1016/j.foreco.2009.12.023

Kuznetsova A, Brockhoff P, RHB C (2017) lmertest package: tests in linear mixed effects models. J Stat Softw 82:1-26

La Porta N, Capretti P, Thomsen IM, Kasanen R, Hietala AM, Von Weissenberg K (2008) Forest pathogens with higher damage potential due to climate change in Europe. Can J Plant Pathol 30:177-195

Laitinen M-L, Julkunen-Tiitto R, Tahvanainen J, Heinonen J, Rousi M (2005) Variation in birch (Betula pendula) shoot secondary chemistry due to genotype, environment, and ontogeny. J Chem Ecol 31:697-717

Lenth R (2020) Emmeans: estimated marginal means, aka least-squares means. R package version 1.4.4. Available at: https://CRAN.Rproject.org/package $=$ emmeans.

Min K, Freeman C, Kang H, Choi S-U (2015) The regulation by phenolic compounds of soil organic matter dynamics under a changing environment. BioMed Res Int 2015:1-11
Moreira X, Mooney KA, Rasmann S, Petry WK, Carrillo-Gavilán A, Zas R, Sampedro L (2014) Trade-offs between constitutive and induced defences drive geographical and climatic clines in pine chemical defences. Ecol Lett 17:537-546

Myking T, Yakovlev I, Ersland GA (2011) Nuclear genetic markers indicate Danish origin of the Norwegian beech (Fagus sylvatica L.) populations established in 500-1,000 AD. Tree genetics \& genomes 7(3):587-596

Nakagawa S, Schielzeth H (2013) A general and simple method for obtaining R2 from generalized linear mixed-effects models. Meth Ecol Evol 4:133-142

NIBIO. (2020). AgroMetBase. Available at: https://lmt.nibio.no/agrom etbase/getweatherdata.php (accessed: 25.02.2020)

Nissinen K, Virjamo V, Randriamanana T, Sobuj N, Sivadasan U, Mehtätalo L, Beuker E, Julkunen-Tiitto R, Nybakken L (2017) Responses of growth and leaf phenolics in European aspen (Рориlus tremula L.) to climate change during juvenile phase change. Can J For Res 47:1350-1363

Nissinen K, Virjamo V, Mehtätalo L, Lavola A, Valtonen A, Nybakken L, Julkunen-Tiitto R (2018) A seven-year study of phenolic concentrations of the dioecious Salix myrsinifolia. J Chem Ecol 44:416-430

Northup RR, Dahlgren RA, McColl JG (1998) Polyphenols as regulators of plant-litter-soil interactions in northern California's pygmy forest: a positive feedback? In: Plant-induced soil changes: processes and feedbacks, Springer, pp. 189-220

Nybakken L, Hörkkä R, Julkunen-Tiitto R (2012) Combined enhancements of temperature and UVB influence growth and phenolics in clones of the sexually dimorphic Salix myrsinifolia. Physiol Plant 145:551-564

Oksanen J, Blanchet FG, Friendly M, Kindt R, Legendre P, McGlinn D, Minchin PR, O'Hara RB, Simpson GL, Solymos P, Stevens MHH, Szoecs E, Wagner H (2019) vegan: Community Ecology Package. R package version 2.5-6. https://CRAN.R-project.org/ package $=$ vegan

Olsen KM, Slimestad R, Lea US, Brede C, Løvdal T, Ruoff P, Verheu M, Lillo C (2009) Temperature and nitrogen effects on regulators and products of the flavonoid pathway: experimental and kinetic model studies. Plant Cell Environ 32:286-299

Osier TL, Lindroth RL (2006) Genotype and environment determine allocation to and costs of resistance in quaking aspen. Oecologia 148:293-303

Pahlsson AMB (1989) Mineral nutrients, carbohydrates and phenoliccompounds in leaves of Beech (Fagus-Sylvatica L) in Southern Sweden as related to environmental-factors. Tree Physiol 5:485495. https://doi.org/10.1093/treephys/5.4.485

Petrakis PV, Spanos K, Feest A, Daskalakou E (2011) Phenols in leaves and bark of Fagus sylvatica as determinants of insect occurrences. Int J Mol Sci 12:2769-2782

$\mathrm{R}$ core team (2019) A language and environment for statistical computing. R Foundation for Statistical Computing, Austria

Robson TM, Sánchez-Gómez D, Cano FJ, Aranda I (2012) Variation in functional leaf traits among beech provenances during a Spanish summer reflects the differences in their origin. Tree Gen Genomes 8:1111-1121

Saltré F, Duputié A, Gaucherel C, Chuine I (2015) How climate, migration ability and habitat fragmentation affect the projected future distribution of European beech. Glob Change Biol 21:897-910

Sampedro L, Moreira X, Zas R (2011) Costs of constitutive and herbivore-induced chemical defences in pine trees emerge only under low nutrient availability. J Ecol 99:818-827

Virjamo V, Sutinen S, Julkunen-Tiitto R (2014) Combined effect of elevated UVB, elevated temperature and fertilization on growth, needle structure and phytochemistry of young Norway spruce (Picea abies) seedlings. Global Ch Biol 20:2252-2260 
Wallis CM, Reich RW, Lewis KJ, Huber DP (2010) Lodgepole pine provenances differ in chemical defense capacities against foliage and stem diseases. Can J For Res 40:2333-2344

Wam HK, Stolter C, Nybakken L (2017) Compositional changes in foliage phenolics with plant age, a natural experiment in boreal forests. J Chem Ecol 43:920-928

Zhang T-J, Zheng J, Yu Z-C, Huang X-D, Zhang Q-L, Tian X-S, Peng C-L (2018) Functional characteristics of phenolic compounds accumulated in young leaves of two subtropical forest tree species of different successional stages. Tree Physiol 38:1486-1501

Zimmer M, Auge H, von Wuhlisch G, Schueler S, Haase J (2015) Environment rather than genetic background explains intraspecific variation in the protein-precipitating capacity of phenolic compounds in beech litter. Plant Ecol Div 8:73-79. https://doi.org/10. 1080/17550874.2013.871655

Zverev E, Kozlov M (2006) Consequences of simultaneous elevation of carbon dioxide and temperature for plant-herbivore interactions: a metaanalysis. Glob Change Biol 12:27-41

Publisher's Note Springer Nature remains neutral with regard to jurisdictional claims in published maps and institutional affiliations. 